\title{
Spatial and Temporal Variation in Rainfall and Groundwater Levels in Kumadvati Watershed in Western Karnataka, India
}

\author{
Lamphrang Laloo ${ }^{1}$, G. Chandrakantha ${ }^{2}$ and Praveen G. Deshbhandari ${ }^{3}$ \\ ${ }^{123}$ Dept. of Applied Geology, Kuvempu University, Jnanasahyadri - 577451 \\ Shivamogga District, Karnataka
}

\begin{abstract}
The climate change along with increasing population has increased the pressure on freshwater resources across the world. Therefore, an attempt has been made in the Kumadvati watershed in western Karnataka, India to know the trends in rainfall and groundwater level. Daily rainfall data of 32 water years from 1984-85 to 2015-16 and monthly groundwater level for the same period has been collected from Government departments, GoK. The Mann-Kendall test along with Sen's slope estimator is used to determine the trends and slope magnitude. The annual and season wise result shows there are increasing and decreasing trends in rainfall. However, the groundwater level shows only decreasing trend in the study area. There is a good correlation between rainfall and groundwater level. The rates of decrease or increase in rainfall and groundwater level in the study are discussed.
\end{abstract}

Key words: Rainfall trend, Groundwater level, Mann-Kendall statistics, Sen's Slope,

\section{INTRODUCTION}

In recent times, climate change is a global phenomenon. Due to climate change, changes in precipitation regimes have affected the availability of water resources in space and time. This has led to damage to agriculture, ecology, and infrastructure, disruption of human activities, injury, and loss of life (Coates, 1996). Rainfall is one of the climatic elements that play an important role in the economic development of a country.

The rainfall intensity and duration vary with space and time. Rainfall analysis carried out by various researchers across the globe has shown an increasing and decreasing trend in rainfall at the regional and local scale (Haylock and Neville, 2000; Brunetti et al., 2000; Gadgil, 2003; Krishna Kumar et al., 2004; Guhathakurta and Rajeevan, 2008; Jain et al., 2013; Gocic and Trajkovic., 2013; Meersmans et al., 2016). Rainfall received in a watershed is an important factor in determining the amount of water available to meet various sectors. If the intensity of precipitation increases can cause flash floods, increase in soil erosion, which often associated with reservoir sedimentation (Suppiah and Hennessy., 1998). On the other hand, if the precipitation decreases, it can deplete the availability of water resources and likely to increase water demand. Changes in precipitation also influence water availability and water quality.

In the context of climatic change and spatial and temporal variability in rainfall, dependence on groundwater has increased. Groundwater is under stress due to an increase in agricultural land and domestic water requirement. The annual water table fluctuation in a water year reflects the volume of groundwater recharge and discharge if the water-bearing properties of the aquifer are known (CGWB, 2009). If recharge exceeds discharge, the volume of water in storage will increase and water levels will rise, if the discharge exceeds recharge, the volume of water in storage will decrease, and water levels will fall. Since recharge and discharge are not distributed uniformly in space and time, groundwater levels rise or fall to adjust to the resulting imbalances. Water levels in wells follow a cyclic pattern that mimics seasonal variations in recharge and discharge. High water levels occur in the rainy season and low water levels occur during the dry summer. The rainfall pattern and its characters are a major controlling factor in the depth of water levels and its annual, seasonal, or decadal fluctuations.

In a hydrological unit, the variability of rainfall in continuum will affect the water table fluctuation. In the hard-rock region, the groundwater resource is less influenced by external factors, unlike surface water resources. Due to over-exploitation of groundwater, the water table is declining at a faster rate (Kulkarni et al., 2004; Panda et al., 2012; Machiwal and Jha, 2014). The porous geological formation where the groundwater gets collected has to be preserved to maintain the existing groundwater regime (Singh and Kasana, 2017). Otherwise, the primary or the secondary porosity in the geological formations is lost or decreases due to external forces, which leads to a decrease in groundwater storage. This results in the loss of freshwater resources due to low groundwater recharge and high surface runoff.

In India, to estimate the volume of groundwater recharge, the water table fluctuation method is adopted (CGWB, 2009). The study of rainfall patterns is very important in understanding spatial and temporal variations in water levels. The impact of temporal variation in rainfall on groundwater level in Shimoga district in the state of Karnataka has not been studied in detail. Hence, a study has been undertaken in Kumadvati watershed to know the trends in rainfall and water level fluctuation.

\section{LOCATION DESCRIPTION:}

The Kumadvati watershed a tributary of the Tungabhadra River lies between $14^{\circ} 08^{\prime} 00^{\prime}$ ' and $13^{\circ} 46^{\prime} 00^{\prime}$ ' N latitude 
and $75^{\circ} 12^{\prime} 00^{\prime}$ ' and $75^{\circ} 28^{\prime} 30^{\prime \prime}$ 'E longitude (Fig. 1). The watershed covers an area of $455 \mathrm{~km}^{2}$ and drains in Thirthhalli, Hosanagara, and Shivamogga taluks in Shimoga district of Karnataka State, India. The elevation of the watershed varies from 522 to $955 \mathrm{~m}$ above mean sea level. The 32 years annual average rainfall of over the watershed is $1830 \mathrm{~mm}$. During the southwest monsoon

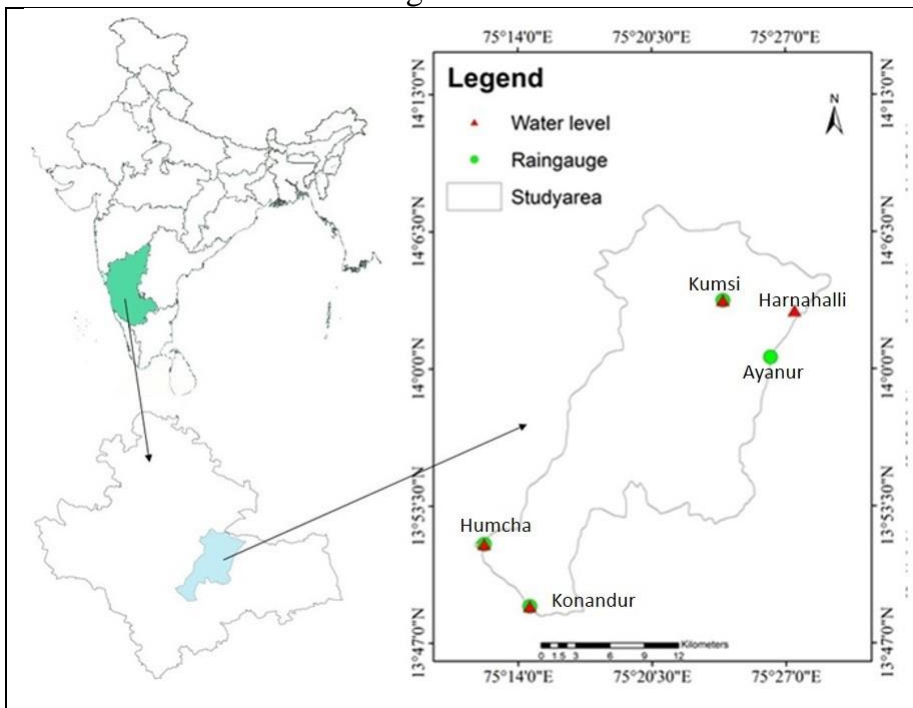

Fig. 1:Location map of Kumadvati Watershed season, the watershed receives $83 \%$ of the annual rainfall and the remaining during the rest of the year. On average, there are 92 rainy days. The rainfall decreases from the southwest towards the northeast direction of the watershed. The spatial variation in annual rainfall in the watershed is shown in Fig. 2.

\begin{tabular}{|l|c|} 
Fig. 1:Location map of Kumadvati Watershed & Fig. 2:Spatial variation in annual average \\
rainfall
\end{tabular}

\section{DATA USED}

Daily rainfall data for rain gauge stations situated in and around the Kumadvati watershed are collected from the district statistical office, GoK for the period from 1984-85 to 2015-16. The Groundwater Division of Dept. of Mines and Geology, GoK monitor the monthly groundwater level in observation wells. The groundwater level data of the observation wells located within the watershed are collected for the period from 1984-85 to 2015-16. The depth to the water table $(\mathrm{m})$ is measured below the ground surface.

\section{DATA PREPARATION}

The annual (Jan -Dec) rainfall and water level data is rearranged to water year (Jun - May). There were some rainfall data missing in some of the stations that were filled in by the average of its neighbouring station method. By the double mass curve method, consistency of the data was checked and found to be consistent. Further, the data has been divided into three seasons, namely monsoon (June Sept), post-monsoon (Oct. - Jan) and pre-monsoon (Jan May). The monthly, seasonal, and annual totals were computed and significant statistical parameters are determined for both rainfall and water level fluctuation data.

\section{Trend analysis}

\section{METHODOLOGY}

In statistics, there are many techniques are available to detect the trend within the time series. WMO (1988) has suggested Mann-Kendall method for assessing trends in meteorological data. According to Hirsch et al., (1991), Mann-Kendall test is preferred when testing different station in the single study. Studies carried out by researchers in India have used Mann-Kendall rank statistics to know the temporal change in annual and season rainfall (Krishna Kumara et al 2004; Jain et al 2013; Mondal et al 2012). Hence, Mann-Kendall test (Mann, 1945; Kendall, 1975) also known as the MK test method is used to study the temporal trend in time series of rainfall and water level data.

The MK test statistic $S$ is calculated using the equation (1).

$$
S=\sum_{k=1}^{n-1} \sum_{j=k+1}^{n} \operatorname{sgn}\left(x_{j}-x_{k}\right)
$$

Where, $x_{j}$ and $x_{k}$ are the data values in time series $\mathrm{j}$ and $\mathrm{k}$ $(j>k)$, and $n$ is the number of data points.

Each of the data point $\mathrm{x}_{\mathrm{j}}$ is taken as a reference point, which is compared with the rest of the data points $x_{k}$. The sign $\left(x_{j}\right.$ $-\mathrm{x}_{\mathrm{k}}$ ) is the sign function calculated using the equation (2).

$$
\operatorname{sgn}\left(x_{j}-x_{k}\right)=\left\{\begin{array}{l}
+1, \text { if } x_{j}-x_{k}>0 \\
0, \text { if } x_{j}-x_{k}=0 \\
-1, \text { if } x_{j}-x_{k}<0
\end{array}\right.
$$

The variance statistic $\mathrm{S}$ is computed using the equation (3).

$$
\operatorname{Var}(S)=\frac{1}{18}\left[n(n-1)(2 n+5)-\sum_{p=1}^{q} t_{p}\left(t_{p}-1\right)\left(2 t_{p}+5\right)\right](3)
$$

Where, $\mathrm{n}$ is the number of data points, $\mathrm{q}$ is the number of tied groups and $t_{p}$ denotes the number of values in the $p^{\text {th }}$ group. A tied group is a set of sample data having the same value.

The standard normal test statistic $\mathrm{Z}$ is calculated using $\mathrm{S}$ and $\operatorname{Var}(S)$ values in the following equation (4). 


$$
Z=\left\{\begin{array}{cc}
\frac{S-1}{\sqrt{\operatorname{VAR}(S)}} & \text { if } S>0 \\
0 & \text { if } S=0 \\
\frac{S+1}{\sqrt{\operatorname{VAR}(S)}} & \text { if } S<0
\end{array}\right.
$$

By evaluating the $\mathrm{Z}$ value, we can find the presence of a statistically significant trend. A positive (negative) value of $\mathrm{Z}$ indicates an upward (downward) trend. A statistic $\mathrm{Z}$ has a normal distribution. To test for either an upward or a downward monotone trend (a two-tile test) at $\alpha$ level of significance, $\mathrm{H}_{0}$ is rejected if the absolute value of $\mathrm{Z}$ is greater than $Z_{1-\alpha / 2}$, where $Z_{1-\alpha / 2}$ is obtained from standard normal cumulative distribution tables. In MAKESENS the tested significance level alpha are $0.001,0.01,0.05$ and 0.1 .

\section{SEN'S SLOPE ESTIMATOR}

The second method of non-parametric procedure for estimating the true slope of an existing trend is developed by Sen's (1968). This method can be used in studies where the trend can be assumed to be linear. This means that $f(t)$ in equation $(5)$ is

$\mathrm{f}(\mathrm{t})=\mathrm{Qt}+\mathrm{B}$

where, $\mathrm{Q}$ is the true slope and B is a constant. To get $\mathrm{Q}$ in the above equation (5), first we have to calculate the slopes of all data value pairs using an equation (6).

$Q_{i}=\frac{x_{j}-x_{k}}{j-k}$ for $\mathrm{i}=1,2,3,4 \ldots \ldots \mathrm{N}$

Where, $j>k, x_{j}$ and $x_{k}$ are the data values at times $j$ and $k$ respectively. The median of these $\mathrm{N}$ values of $\mathrm{Q}_{\mathrm{i}}$ is represented as Sen's estimator of slope.

If there are $n$ values, $x_{j}$ is the time series, we get as many as $\mathrm{N}=\mathrm{n}(\mathrm{n}-1) / 2$ slope estimates $\mathrm{Q}_{\mathrm{i}}$. The Sen's estimator of slope is the median of these $\mathrm{N}$ values of $\mathrm{Q}_{i}$. The $\mathrm{N}$ values of $\mathrm{Q}_{i}$ are ranked from the smallest to the largest and the Sen's estimator is computed as:

$Q=Q_{\left[\frac{(N+1)}{2}\right],}$ if $N$ is odd

$Q=\frac{1}{2}\left(Q_{\left[\frac{N}{2}\right]}+Q_{\left[\frac{N+2}{2}\right]}\right)$, if $\mathrm{N}$ is even
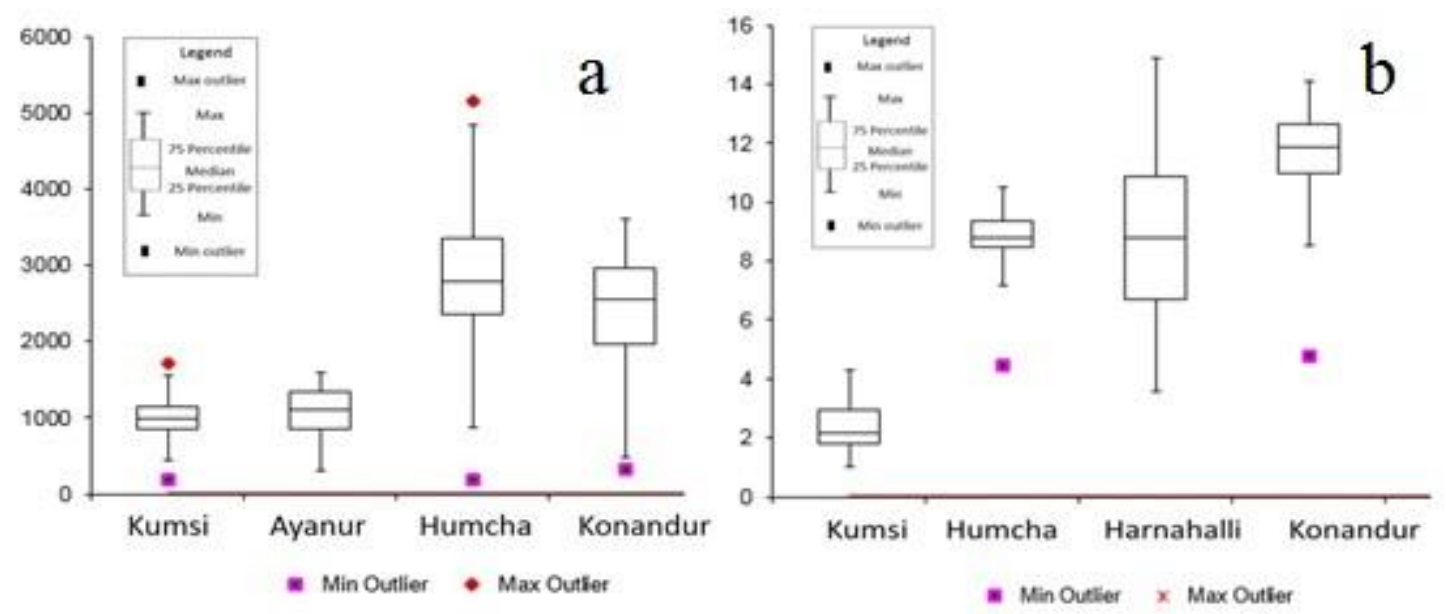

Figure 3: Box and Whisker Plot of 32 years annual rainfall (a) and Water level fluctuation (b)
By the non-parametric technique based on the normal distribution, $\mathrm{Q}_{\text {med }}$ is computed by a two sided test at 100(1$\alpha) \%$ confidence interval and the true slope is obtained. This is valid for $\mathrm{n}$ as small as 10 unless there are many ties.

If $\mathrm{Q}_{\mathrm{i}}$ value is positive, it indicates an upward or increasing trend and if $\mathrm{Q}_{\mathrm{i}}$ values are negative, it indicates downward or decreasing trend in the time series.

\section{Change magnitude of trend as percentage of mean}

The percentage change is computed using the equation (8) by approximating it with a linear trend.

Percentage change $(\%)=\frac{Q \times \text { length of year }}{\text { mean }} \times 100$

(8)

\section{Rainfall Trend Analysis}

\section{RESULTS AND DISCUSSIONS:}

The rainfall record at different stations in the watershed is analysed individually and the results of statistical analysis are shown in Table 1 . Lowest annual precipitation of 758 $\mathrm{mm}$ is recorded in Ayanur station in the year 2001-02 and highest rainfall of $5153 \mathrm{~mm}$ records in Humcha station in the year 1994-95. The annual spatial rainfall distribution map (Fig.2) shows that the southwest portion of the watershed receives the highest rainfall and decreases towards the northeast direction in the watershed. On average, the watershed receives $1830 \mathrm{~mm}$ of rainfall annually.

The variation of annual rainfall at four rain gauge stations of the study area is shown using Box and Whisker plots (Fig.3). From the figure, it is evident that the annual rainfall at Humcha and Konandur stations is more than the average rainfall of the watershed. These stations are located in the southern part of the watershed where the forest cover is more. At Kumsi and Ayanur stations, it is less than the annual average rainfall of the watershed. These stations are located in the northern part of the watershed. The rainfall distribution at Kumsi and Ayanur stations is low, whereas at Humcha and Konandur it is more. 
Table.1: Significant Statistical parameters of Rainfall and Groundwater Level in Kumadvati Watershed

\begin{tabular}{|c|c|c|c|c|c|c|c|c|c|}
\hline \multirow{2}{*}{ Seasons } & \multicolumn{5}{|c|}{ Rainfall } & \multicolumn{4}{|c|}{ Groundwater level } \\
\hline & & Kumsi & Ayanur & Humcha & Konandur & Kumsi & Humcha & Harnahalli & Konandur \\
\hline \multirow{5}{*}{ Annual } & Mean & 1022 & 1106 & 2847 & 2471 & 2.3 & 8.7 & 9.1 & 11.4 \\
\hline & Median & 997 & 1111 & 2777 & 2559 & 2.1 & 8.8 & 9.0 & 11.8 \\
\hline & $\begin{array}{l}\text { Standard } \\
\text { Deviation }\end{array}$ & 231 & 288 & 897 & 628 & 0.8 & 1.1 & 3.0 & 2.1 \\
\hline & Minimum & 712 & 604 & 1078 & 1313 & 1.0 & 4.5 & 3.6 & 4.8 \\
\hline & Maximum & 1709 & 1594 & 5153 & 3598 & 4.3 & 10.5 & 14.9 & 14.1 \\
\hline \multirow{5}{*}{$\begin{array}{l}\text { Monsoon(Jun to } \\
\text { Sept) }\end{array}$} & Mean & 771 & 817 & 2473 & 2174 & 1.6 & 7.0 & 8.3 & 10.0 \\
\hline & Median & 750 & 753 & 2468 & 2212 & 1.4 & 7.4 & 8.3 & 10.3 \\
\hline & $\begin{array}{l}\text { Standard } \\
\text { Deviation }\end{array}$ & 157 & 192 & 823 & 605 & 0.7 & 1.7 & 2.9 & 2.9 \\
\hline & Minimum & 572 & 559 & 853 & 1018 & 0.5 & 2.3 & 3.6 & 2.7 \\
\hline & Maximum & 1138 & 1189 & 4489 & 3380 & 3.4 & 9.5 & 14.6 & 14.0 \\
\hline \multirow{5}{*}{$\begin{array}{c}\text { Post- } \\
\text { Monsoon(Oct to } \\
\text { Jan) }\end{array}$} & Mean & 187 & 193 & 236 & 215 & 1.9 & 8.1 & 7.9 & 10.8 \\
\hline & Median & 163 & 178 & 210 & 188 & 1.8 & 8.4 & 7.5 & 11.2 \\
\hline & $\begin{array}{l}\text { Standard } \\
\text { Deviation }\end{array}$ & 95 & 72 & 125 & 83 & 0.7 & 1.3 & 3.7 & 2.2 \\
\hline & Minimum & 91 & 82 & 100 & 122 & 0.4 & 2.6 & 1.8 & 2.3 \\
\hline & Maximum & 579 & 356 & 607 & 471 & 4.1 & 9.7 & 15 & 13.2 \\
\hline \multirow{5}{*}{$\begin{array}{c}\text { Pre- } \\
\text { Monsoon(Feb to } \\
\text { May) }\end{array}$} & Mean & 98 & 135 & 165 & 121 & 3.6 & 10.9 & 11.2 & 13.5 \\
\hline & Median & 85 & 135 & 137 & 125 & 3.4 & 11.1 & 11.0 & 13.8 \\
\hline & $\begin{array}{l}\text { Standard } \\
\text { Deviation }\end{array}$ & 57 & 64 & 136 & 62 & 1.2 & 1.0 & 3.0 & 1.4 \\
\hline & Minimum & 11 & 42 & 41 & 16 & 1.1 & 8.5 & 4.8 & 9.3 \\
\hline & Maximum & 237 & 285 & 823 & 300 & 5.9 & 12.6 & 15.7 & 15.4 \\
\hline
\end{tabular}

To know the annual rainfall trend in the watershed, the MK test $(Z)$ and Sen's slope estimator has been carried out and the results represent both positive and negative trends (Table 2). From Table 2, $\mathrm{Z}$ statistics reveal the rainfall trend during different seasons in different stations. Except Humcha, all other station shows an increasing trend in annual and monsoon rainfall, whereas during postmonsoon and pre-monsoon season shows decreasing trend and increasing trends respectively in all stations. In a study by Naidu et al (1999) also concluded that a positive trend is present in the Kumadvati watershed region by analysing 124 years rainfall data.

During the post - monsoon, decreasing trend in the precipitation records found to be statistically significant at the $10 \%$ level at Humcha and 5\% significant level at Ayanur and Konandur during pre-monsoon. In other stations, trend in rainfall are not significant. The Sen's slope estimator of rainfall results shows that the annual change magnitude of trend at Kumsi, Ayanur, Humcha and Konandur is $22.4 \%, 30 \%,-16.9 \%$ and $10.8 \%$ respectively. The change magnitude observed at Humcha is $-69.6 \%$, $3.7 \%,-42.2 \%$ and $-2.8 \%$ during annual, monsoon, postmonsoon and pre-monsoon respectively.

In three stations, namely Kumsi, Ayanur and Konandur, Sen's slope percentage change is positive for annual, monsoon and pre-monsoon seasons, whereas at Humcha show increasing trend only during pre-monsoon and decreasing trend for annual and other two seasons. The annual decrease in rainfall at Humcha station is $19.17 \mathrm{~mm} /$ year. In Kumsi, Ayanur and Konandur stations, the annual increase in rainfall is $2.7 \mathrm{~cm} /$ year, $7.4 \mathrm{~cm} /$ year and $9.0 \mathrm{~cm} /$ year respectively (Table 3 ). The rainfall trend in four stations for annual, monsoon, post-monsoon and premonsoon is shown in Fig. 4.

Table 2: Values of significant trend in Rainfall

\begin{tabular}{|c|c|c|c|c|c|c|c|c|c|c|c|c|}
\hline & \multicolumn{3}{|c|}{ Annual } & \multicolumn{3}{|c|}{ Monsoon } & \multicolumn{3}{|c|}{ Post-Monsoon } & \multicolumn{3}{|c|}{ Pre-Monsoon } \\
\hline Stations & Test Z & $\mathbf{Q}$ & $\%$ & Test Z & $\mathbf{Q}$ & $\%$ & Test Z & $\mathbf{Q}$ & $\%$ & Test $Z$ & $\mathbf{Q}$ & $\%$ \\
\hline Kumsi & 1.3 & 6.91 & 22.4 & 1.5 & 6.11 & 27.1 & -1.1 & -2.0 & -37.6 & 1.3 & 1.8 & 60.1 \\
\hline Ayanur & 1.4 & 10.11 & 30.0 & 1.4 & 8.06 & 33.5 & -0.2 & -0.4 & -7.2 & $2.0 *$ & 2.9 & 71.3 \\
\hline Humcha & -0.7 & -14.9 & -16.9 & -0.8 & -12.5 & -16.3 & $-1.9^{+}$ & -5.8 & -87.1 & 1.6 & 3.15 & 64.1 \\
\hline Konandur & 0.7 & 8.25 & 10.8 & 0.7 & 11.54 & 17.2 & -1.1 & -1.9 & -33.1 & $2.0 *$ & 2.9 & 83.9 \\
\hline
\end{tabular}

Z - Mann-Kendall test, Q - Sen's slope estimator.*** Statistically significant at $0.1 \%$ level of significance. * Statistically significant at $5 \%$ level of significance.+ Statistically significant at $10 \%$ level of significance.

The MK test trend values obtained for annual rainfall is used to show spatial trend in the watershed using Arc-GIS software (Fig.6a). The highest trend value is 1.65 and the lowest is -0.55 . The map shows an increasing trend in rainfall from south to north. The linear equations obtained from the trend lines of annual rainfall at different stations are shown in Table 3. 
Table 3: Linear equations of the trend lines for annual rainfall and groundwater level

\begin{tabular}{|l|l|l|l|}
\hline \multicolumn{1}{|c|}{ Rainfall } & \multicolumn{1}{c|}{ Linear equation } & \multicolumn{1}{c|}{ Groundwater Level } & \multicolumn{1}{c|}{ Linear equation } \\
\hline Kumsi & $\mathrm{y}=2.7602 \mathrm{x}+970.6$ & Kumsi & $\mathrm{y}=-0.0468 \mathrm{x}+3.1225$ \\
\hline Humcha & $\mathrm{y}=-19.166 \mathrm{x}+3159.9$ & Humcha & $\mathrm{y}=-0.0023 \mathrm{x}+8.6078$ \\
\hline Ayanur & $\mathrm{y}=7.4158 \mathrm{x}+964.67$ & Harnahalli & $\mathrm{y}=-0.123 \mathrm{x}+11.095$ \\
\hline Konandur & $\mathrm{y}=9.0066 \mathrm{x}+2322.2$ & Konandur & $\mathrm{y}=0.00297 \mathrm{x}+10.908$ \\
\hline
\end{tabular}
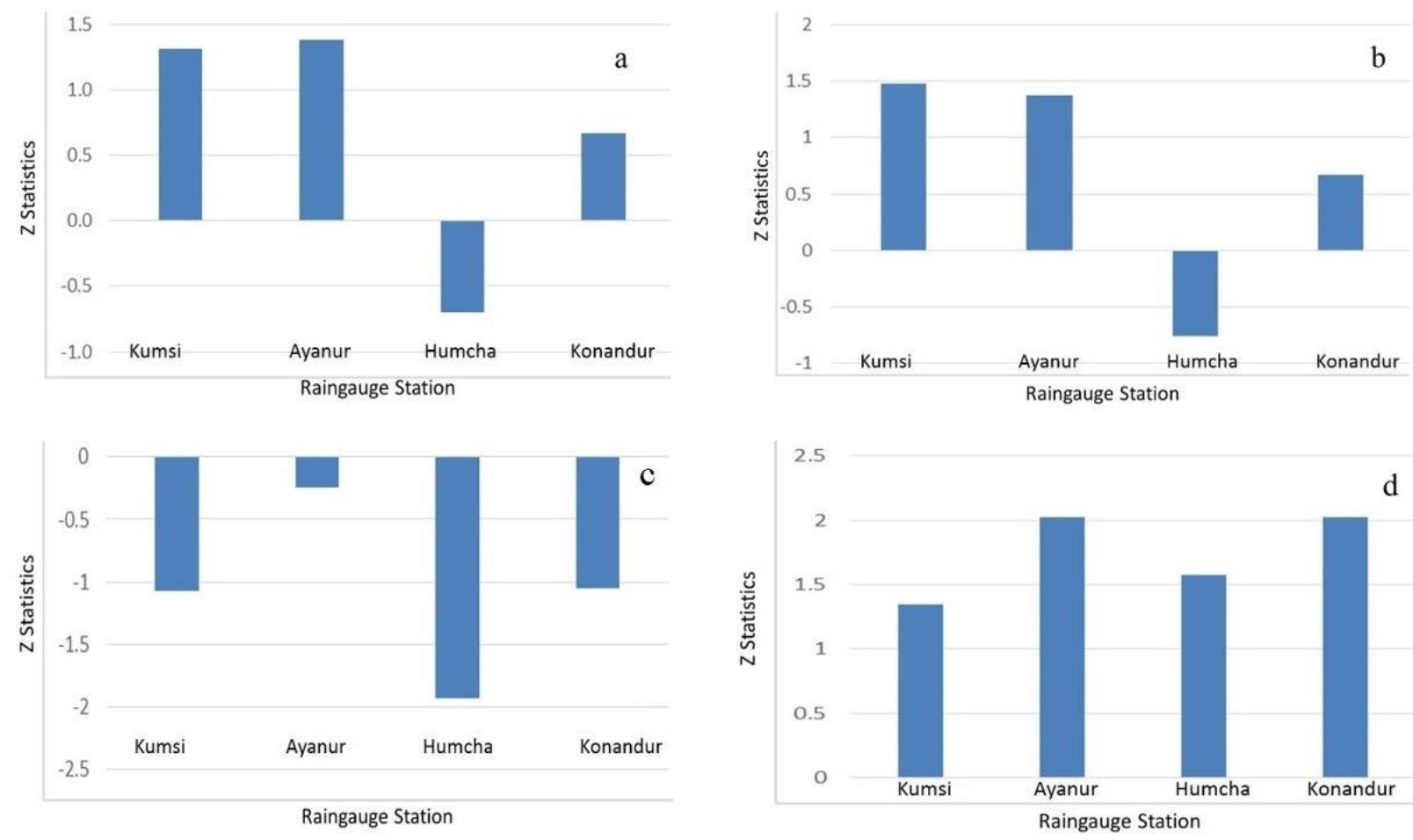

Figure 4: Trend of Z for Rainfall - Annual (a), Monsoon (b), Post-Monsoon (c), and Pre-Monsoon (d)

\section{WATER LEVEL FLUCTUATION}

The annual groundwater level fluctuation data is shown using Box and Whisker plots (Fig 3). Maximum water level fluctuation observed at Harnahalli station where the high irrigation activity and settlements are located. At Humcha station, the water level fluctuation is less and is located closer to forest land, where irrigation activity and population is less.

The results of groundwater level trends in all four stations during annual, monsoon and pre-monsoon seasons show a positive trend at Humcha, and Konandur stations, whereas at Kumsi and Harnahalli wells show a negative trend (Table. 4 and Fig. 5). The negative trend is mainly because the groundwater recharge during the monsoon season has decreased in the watershed due to change in LULC. The large area has been brought under irrigation in the recent times and in addition, during the post-monsoon season, groundwater extraction has increased in the watershed for irrigation and domestic water supply. Earlier people in the watershed use to grow rain-fed crops like paddy during monsoon season only. Now they have switched over to plantation crops due to labour problem. These plantation crops require irrigation during other seasons also. Hence, the groundwater shows declining trend.

The MK test $(Z)$ and the Sen's slope estimator has been carried out to know the groundwater level trend and is tabulated in Table 4. The $\mathrm{Z}$ statistics reveal that the groundwater level shows a decreasing trend in all the observation wells except during pre-monsoon season. At Kumsi station, the trend found to be statistically significant at the $0.1 \%$ level of significance during annual, monsoon, and pre-monsoon seasons. In post-monsoon season statistically significant at $10 \%$ level of significance. At Harnahalli station, the trend found to be statistically significant at the $0.5 \%$ level of significance during annual, post-monsoon, and pre-monsoon. 
Table 4: Values of significant trend of water level fluctuation

\begin{tabular}{|l|c|c|c|c|c|c|c|c|c|c|c|c|}
\hline \multicolumn{1}{|c|}{ 1984-2015 } & \multicolumn{3}{|c|}{ Annual } & \multicolumn{3}{c|}{ Monsoon } & \multicolumn{3}{c|}{ Post-Monsoon } & \multicolumn{3}{c|}{ Pre-Monsoon } \\
\hline & Test Z & $\mathbf{Q}$ & $\%$ & Test Z & $\mathbf{Q}$ & $\%$ & Test Z & $\mathbf{Q}$ & $\%$ & Test Z & $\mathbf{Q}$ & $\mathbf{\%}$ \\
\hline Kumsi & $-3.7^{* * *}$ & -0.05 & -69.6 & $-3.62^{* * *}$ & -0.05 & -100 & $-1.67+$ & -0.02 & -33.7 & $-3.45^{* * *}$ & -0.08 & -71.1 \\
\hline Humcha & -1.1 & -0.01 & -3.7 & -0.89 & -0.03 & -13.7 & -0.79 & -0.02 & -7.9 & 0.23 & 0.01 & 2.9 \\
\hline Harnahalli & $-2.1 *$ & -0.12 & -42.2 & -1.35 & -0.08 & -30.8 & $-2.29 *$ & -0.14 & -56.7 & $-2.35^{*}$ & -0.15 & -42.9 \\
\hline Konandur & -0.4 & -0.01 & -2.8 & -0.50 & -0.04 & -12.8 & -0.31 & -0.01 & -3.0 & 1.14 & 0.02 & 4.7 \\
\hline
\end{tabular}

Z - Mann-Kendall test, Q - Sen's slope estimator.*** Statistically significant at $0.1 \%$ level of significance. * Statistically significant at $5 \%$ level of significance. + Statistically significant at $10 \%$ level of significance

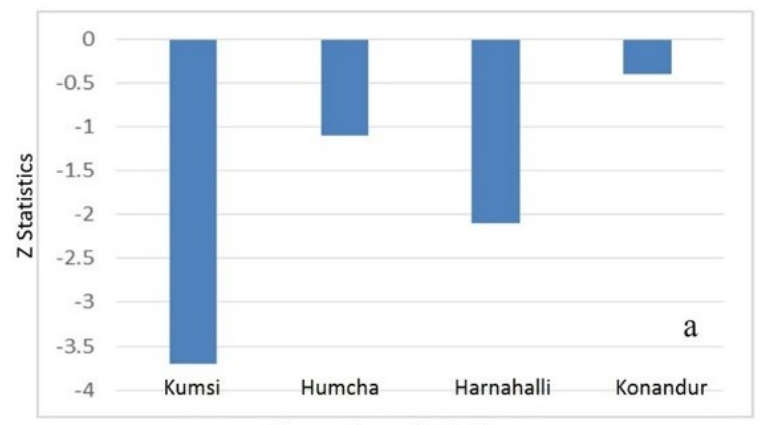

Observation wells Station

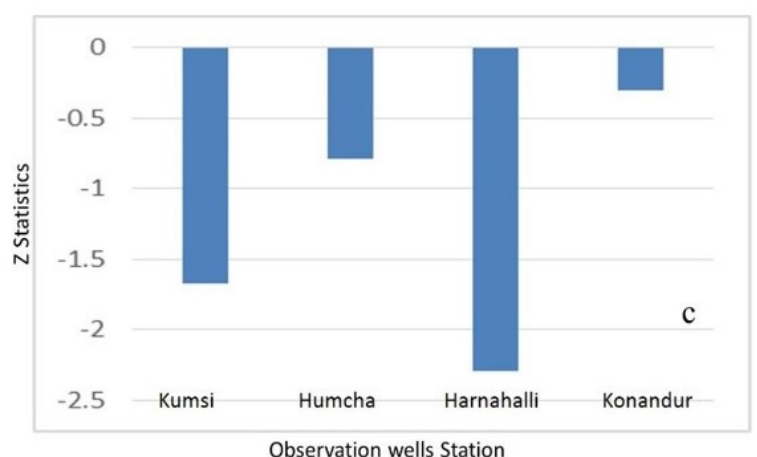

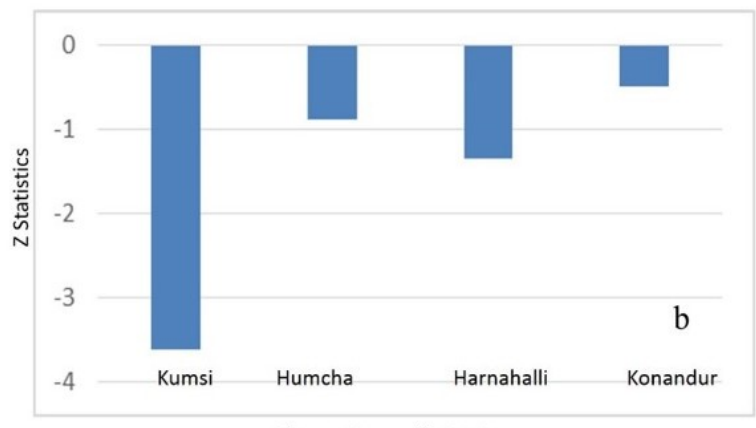

Observation wells Station

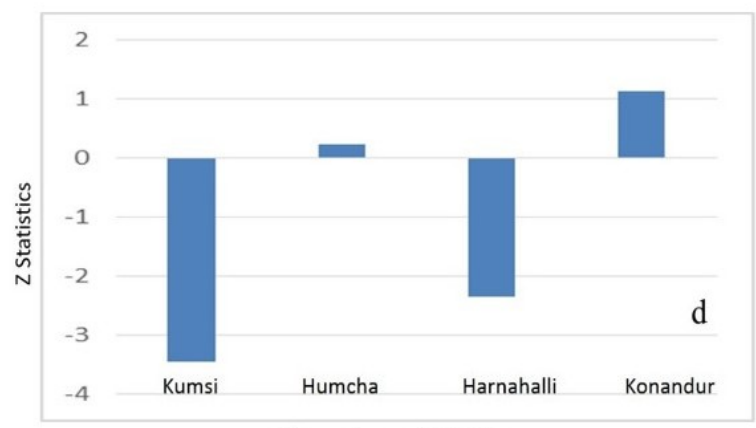

Observation wells Station

Figure 5: Trend of Z for Water level - Annual (a), Monsoon (b), Post-Monsoon (c), and Pre-Monsoon (d)

The trend values obtained from MK test for water level are used to show the trend in water levels in the watershed (Fig. 6b).The maximum and minimum decrease trend in water level in the watershed varies from -1.3 to $-5.2 \mathrm{~m}$. This decreasing trend increases from the southern part towards the northern part of the watershed. The higher values of a decreasing trend in the northern part are due to increase in irrigation activity and population. The annual water level fluctuation trend line equations for the observation wells are given in Table 3. The decrease in water level at Harnahalli is $12 \mathrm{~cm} /$ year and Kumsi it is $5 \mathrm{~cm} /$ year. In other two stations, the decrease in groundwater level is negligible. 


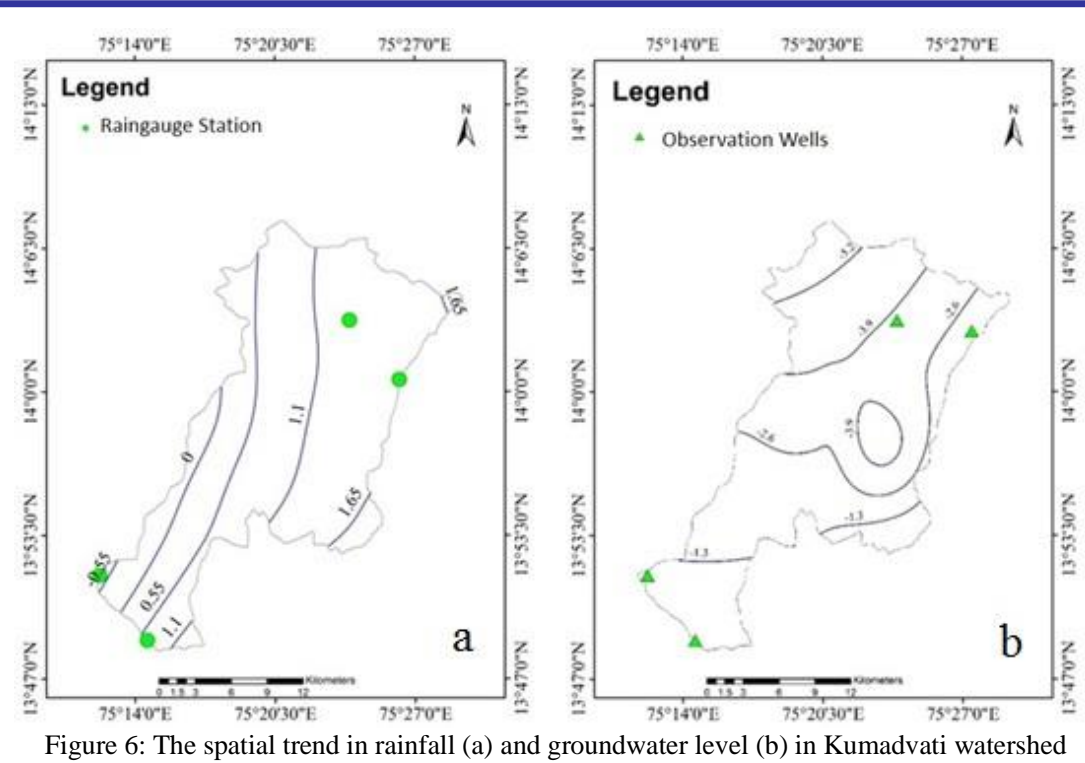

\section{GROUNDWATER LEVEL IN RELATION TO \\ RAINFALL}

To know the relationship between rainfall and groundwater levels of the observation wells in the study area, 32 years annual rainfall and groundwater levels are plotted for three stations (Fig 7). The rate of increase in water level in the wells depends on the intensity and duration of the rainfall. If both intensity and duration is more, the groundwater recharge will be more, the water level increases quickly. Otherwise, if the duration of rainfall is less even if the annual rainfall is equal to average rainfall, the rate of recharge decreases and in turn increase in water level is also less.

The Humcha, and Konandur stations shows a good correlation between the water level and the rainfall. These two stations are located in the southern side of the watershed and they are close to forestland. At these stations, the ground slope is high since they are located along the foothills of the Western Ghats. Hence, in-spite of receiving high rainfall, groundwater recharge is moderate. The annual fluctuation in these stations is very low due to less population and irrigation activity. The observation wells at Kumsi and Harnahalli are in the northern part of the watershed where the slope is less and recharge is more. Hence, in these observation wells, the groundwater level reaches close to the ground surface during monsoon season. The yearly water level fluctuation in these observation wells is more due to unsustainable withdrawal of groundwater for domestic and irrigation purposes.

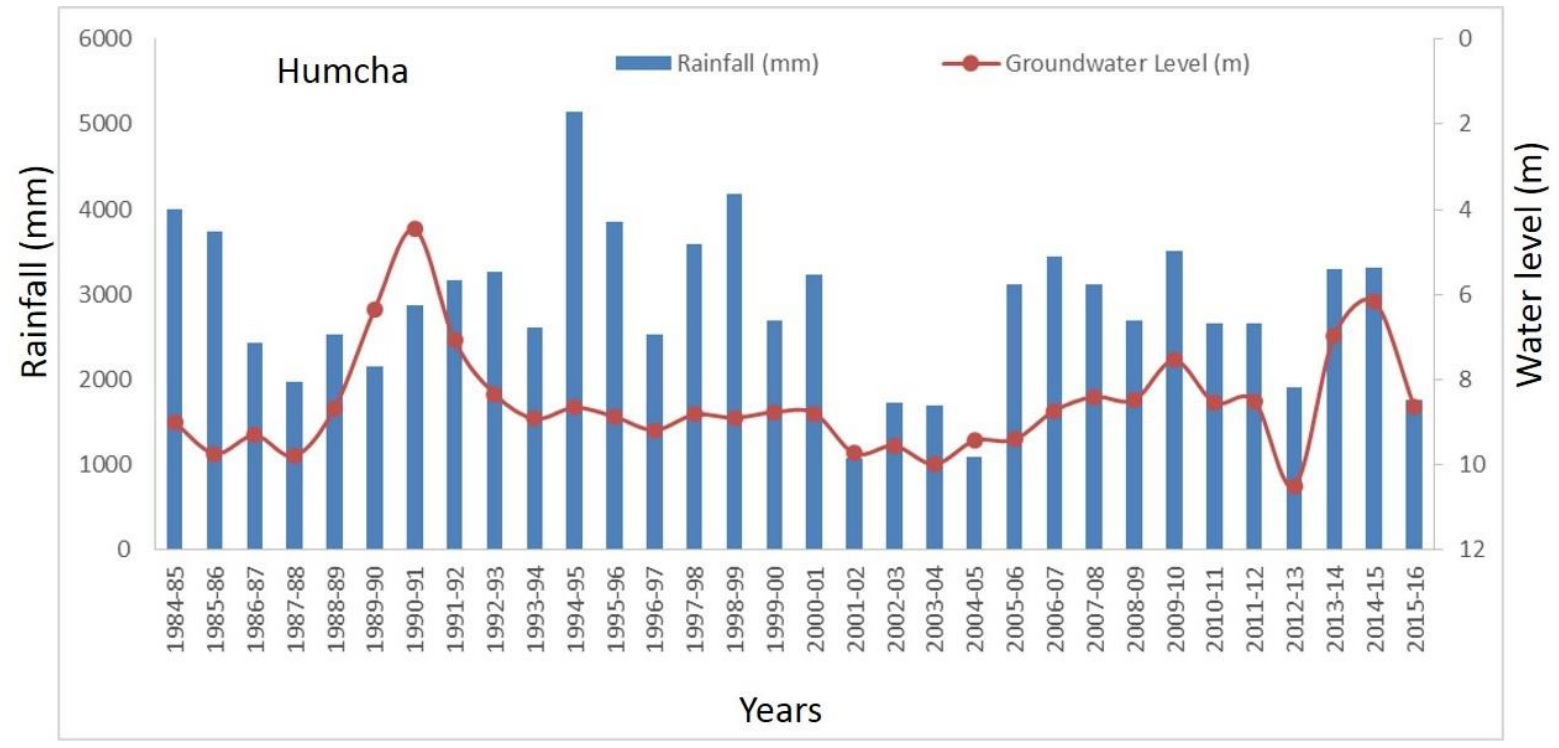




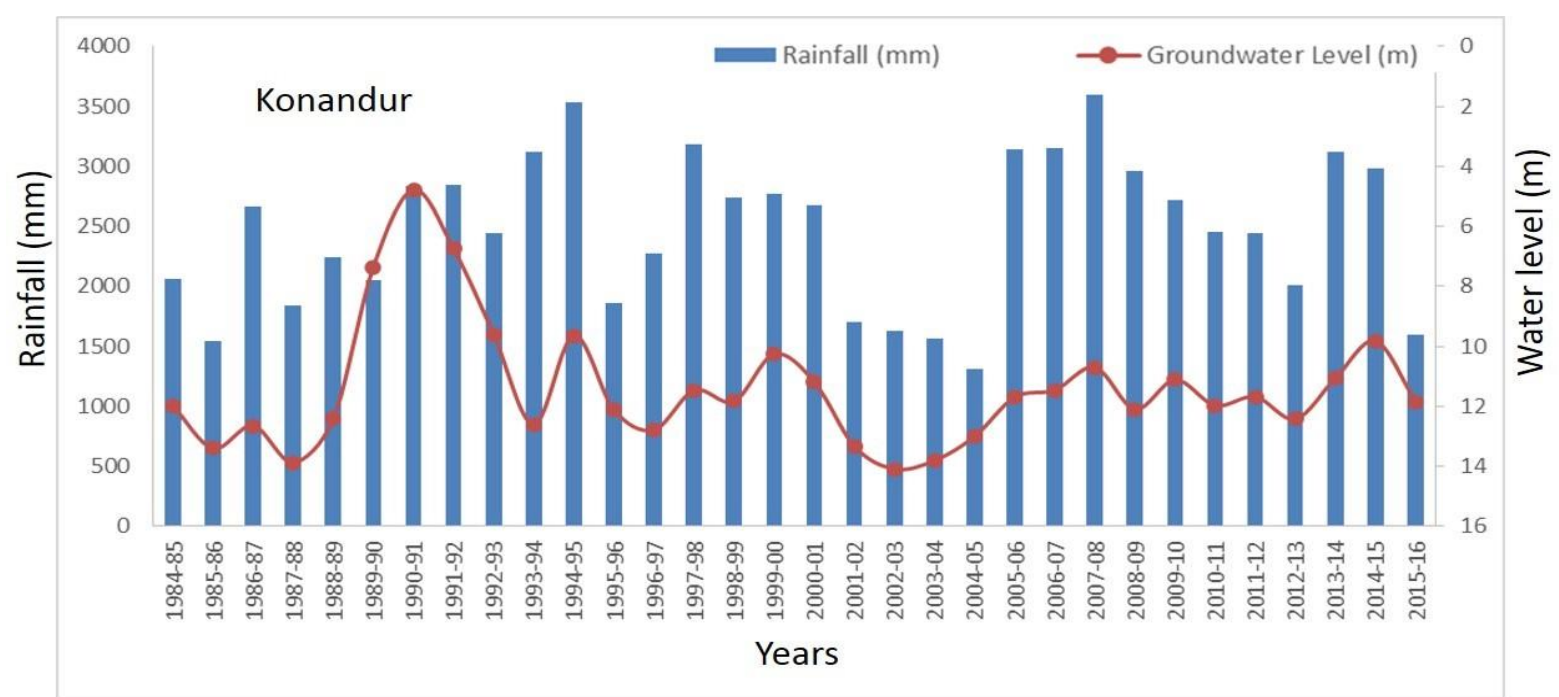

Fig 7: Relationship between rainfall Vs groundwater level at Humcha and Konandur stations in Kumadvati watershed

\section{CONCLUSIONS}

In the present study, analysis of 32 years of rainfall and groundwater level in Kumadvati watershed for the period from 1984-85 to 2015-16 has been analysed to know the spatial and temporal trend. The Mann-Kendall test used to know the trend in annual rainfall shows there is an increasing and decreasing trend in the stations. The rainfall increases from south towards the north. At Humcha the annual, monsoon and post-monsoon season shows decreasing trend. At Kumsi, Ayanur and Konandur stations show an increasing trend in rainfall for annual, monsoon, and pre-monsoon. In general, the groundwater level in the study area shows a decreasing trend annually. The spatial maps show-decreasing trend in rainfall and groundwater levels in the study area. The relationship between rainfall and water level show a good correlation at Humcha and Konandur stations. The decrease in water level during the study period at Kumsi and Harnahalli is due to increase in irrigation area and population in the northern part of the watershed.

\section{ACKNOWLEDGEMENT:}

The authors gratefully acknowledge the facilities provided by the Chairman, Dept. of Applied Geology, Kuvempu University and the statistical department and Groundwater division of Mines and Geology, Govt. of Karnataka for providing necessary data for the present study. The first author is thankful to Kuvempu University for the award of University fellowship for pursuing Ph.D. Degree program.

\section{REFERENCES:}

[1] Brunetti, M., Buffoni, L., Maugeri, M., \& Nanni, T. (2000): Precipitation intensity trends in northern Italy. International Journal of Climatology: A Journal of the Royal Meteorological Society, 20(9), 1017-1031.

[2] CGWB (2009): Ground water resource estimation methodology, Ministry of Water Resources Government of India, NEW DELHI.

[3] Coates, L. (1996): An overview of fatalities from some natural hazards in Australia. In Conference on Natural Disaster Reduction 1996: Conference Proceedings (p. 49). Institution of Engineers, Australia.
[4] Gadgil, S. (2003): The Indian monsoon and its variability. Annual Review of Earth and Planetary Sciences, 31(1), 429467.

[5] Gocic, M., \& Trajkovic, S. (2013): Analysis of changes in meteorological variables using Mann-Kendall and Sen's slope estimator statistical tests in Serbia. Global and Planetary Change, 100, 172-182.

[6] Guhathakurta, P., \& Rajeevan, M. (2008): Trends in the rainfall pattern over India. International Journal of Climatology: A Journal of the Royal Meteorological Society, 28(11), 1453-1469.

[7] Haylock, M., and Neville, N. (2000): Trends In Extreme Rainfall Indices For An Updated High Quality Data Set For Australia, 1910-1998. Int. J. Climatol. 20: 1533-1541

[8] Hirsch, R. M., Alexander, R. B., \& Smith, R. A. (1991): Selection of methods for the detection and estimation of trends in water quality. Water resources research, 27(5), 803-813.

[9] Jain, S. K., Kumar, V., \& Saharia, M. (2013): Analysis of rainfall and temperature trends in northeast India. International Journal of Climatology, 33(4), 968-978.

[10] Kendall, M.G.(1975): Rank Correlation Methods. Griffin, London, UK.

[11] Krishna Kumar, K., Rupa Kumar, K., Ashrit, R. G., Deshpande, N. R., \& Hansen, J. W. (2004): Climate impacts on Indian agriculture. International Journal of Climatology: A Journal of the Royal Meteorological Society, 24(11), 13751393.

[12] Kulkarni, H., Shankar, P. V., Deolankar, S. B., \& Shah, M. (2004): Groundwater demand management at local scale in rural areas of India: a strategy to ensure water well sustainability based on aquifer diffusivity and community participation. Hydrogeology Journal, 12(2), 184-196.

[13] Machiwal, D., \& Jha, M. K. (2014): Characterizing rainfallgroundwater dynamics in a hard-rock aquifer system using time series, geographic information system and geostatistical modelling. Hydrological Processes, 28(5), 2824-2843.

[14] Mann, H. B. (1945): Nonparametric tests against trend. Econometrica: Journal of the Econometric Society, 245-259.

[15] Meersmans, J., VanWeverberg, K., De Baets, S., De Ridder, F., Palmer, S. J., van Wesemael, B., \&Quine, T. A. (2016): Mapping mean total annual precipitation in Belgium, by investigating the scale of topographic control at the regional scale. Journal of Hydrology, 540, 96-105.

[16] Mondal, A., Kundu, S., \& Mukhopadhyay, A. (2012): Rainfall trend analysis by Mann-Kendall test: A case study of northeastern part of Cuttack district, Orissa. International Journal of Geology, Earth and Environmental Sciences, 2(1), 70-78. 
[17] Naidu, C. V., Rao, B. S., \& Rao, D. B. (1999): Climatic trends and periodicities of annual rainfall over India. Meteorological Applications, 6(4), 395-404.

[18] Panda, D. K., Mishra, A., \& Kumar, A. (2012): Quantification of trends in groundwater levels of Gujarat in western India. Hydrological sciences journal, 57(7), 1325-1336.

[19] Sen, P. K. (1968): Estimates of the regression coefficient based on Kendall's tau. Journal of the American statistical association, 63(324), 1379-1389.

[20] Singh, O., \& Kasana, A. (2017): GIS-based spatial and temporal investigation of groundwater level fluctuations under rice-wheat ecosystem over Haryana. Journal of the Geological Society of India, 89(5), 554-562.

[21] Suppiah, R.,\& Hennessy, K. J. (1998): Trends in total rainfall, heavy rain events and number of dry days in Australia, 1910 1990. International Journal of Climatology: A Journal of the Royal Meteorological Society, 18(10), 1141-1164.

[22] WMO (1988): Analyzing long time series of hydrological data with respect to climate variability. World Meteorological Organization (WMO): WCAP-3, WMO/TD-No: 224, Switzerland, pp. $1-12$ 